\title{
DUVAL'S INTRODUCTIONS
}

\author{
TRANSLATED By SAMUEL BARRY
}

The following is an English translation of Duval's Preface to the first fascicule as well as his lengthy Introduction to the edition. This translation, by Samuel Barry, was produced as part of his Fellowship program at Beth Mardutho during 20I8. This Fellowship was supported by Dr. Khalid and Mrs. Amira Dinno of Toronto.

\section{PREFACE TO THE FIRST FASCICULE}

The first fascicule of Bar Bahlul's Lexicon, which I hand over to your judgment, kind reader, consists only of a series of words beginning in ālap. That indeed a single letter may extend across the space of 348 large columns should not seem surprising to you, given that you will discover upon examination, in part, a mass of Greek words collected and added to these lines. The author here collected words beginning with vowels as well as with diphthongs, being $\alpha, \alpha v, \alpha l, \varepsilon, \varepsilon v, \varepsilon l, \eta, l, 0,0 l, 0 v, v$, as well as words beginning with certain consonants, such as $\sigma$ and $\sigma \tau$; in addition to the above, he has not rarely insinuated other words rendered erroneous due to corruption. As the remaining twenty-one letters each will occupy much less space, I take it for certain that it will be easy to divide (the entire lexicon) into four fascicules. The first part, now departing for the presses, was the work of the preceding I8 months; as I am confident that bringing to light a single one of the others which will follow hereafter will take about the same span of time, it is thus to be greatly hoped that the whole of the work will be brought to a close by the year I893, or, if later, not after I894. Truly a long time! As a question of emotion, I know well that it would be much to be preferred for the lexicon to be published as a whole with complete critical apparatus and indices, rather than to be published in parts, both in terms of ease and of (public) perception; but, as a question of reason, it seems preferable not to delay any longer. 
I completed long ago the preface which I have in mind to give to the book, but it seems preferable to hand over the entire work to the press at last, for certain obscurities that would occur if such were done now will be avoided in doing so. The subjects treated in the preface are: I. The origin and the composition of the lexicons; 2 . The method of editing; 3. The authorities and sources cited by Bar Bahlul; 4. the Aramaic dialects named in the lexicon; 5. The manuscripts of the lexicon preserved in Europe; 6. The Syriac and Arabic prefaces which Bar Bahlul affixed to his work, Latin translations of which will be provided.

The indices will include: $\mathrm{I}$. Syriac words arranged according to the order of their roots; 2 . Arabic words of interest to note on account of their form or sense, in particular the names of plants; 3. Persian words; 4. Hebrew words; 5. Biblical texts cited or interpreted in the lexicon. Moreover, the Greek words that occur most frequently would seem to be of little importance for the study of Greek; it is clear that the greater part of these comes from translations of Greek books into Syriac, or out of Greek glosses in the margins of Syriac manuscripts written in the lexicons of Bar 'Ali and Bar Bahlul, many of which are erroneous or corrupt; what little care was given to restoring these to their Greek form was employed inconsiderately. Other words, no doubt, which passed over to the Syriac language would have been subject to various changes in the mouths of the Syrians, but not many derive from such sources as would allow for the Greek dialects customary in Asia to be investigated. Nevertheless, although these words are weak in themselves, they display particular utility by (virtue of) the Syriac and Arabic glosses which follow them. Of these, certainly, the many names of animals and plants they preserve whose senses appear clear may securely be investigated here; this is the core of the lexicon. For these reasons it does not seem appropriate to me to arrange the Greek words in alphabetical order, (but rather) to add to the first fascicule an appendix that will allow for them to be consulted according to their place in the lexicon, thus allowing for the form of the Greek words to be restored. Whenever a word is repeated in various places in the section for the letter ālap, the subsequent instances will be noted with the initial instance; if in fact (that word) is repeated under another letter, that instance will not be noted, unless it is convenient; for example, concerning words beginning with the vowel $\varepsilon$ or the consonants $\sigma$ and $\sigma \tau$ collected in the section for alap, very many of these will be repeated in the sections for the letter $m$ and the letter $\varphi$; in the appendix to section ālap, no reference will be made to the presence of these words in sections $m$ and $\varphi$.

In the introduction, as I mentioned before, the codices of the lexicon will be discussed extensively. Here it would not be inappropriate to include a few notes for un- 
derstanding certain abbreviations which will be encountered in these pages. It is known that the codices number 13 , which I note in the following sequence:

A. Anglicus, Kept in the British Museum under shelfmark 244I.

B. Beroliniensis, Kept in the Royal Library of Berlin under shelfmark $212-2 \mathrm{I} 3$ in the Sachau collection.

$\mathrm{B} b$. Shelfmark 194 in the same collection.

$\mathrm{B} b b$. Shelfmark 395 in the same collection.

$\mathrm{B} b b b$. Shelfmark $\mathrm{I} 7 \mathrm{I}$ in the same collection.

C. Cantabrigiensis, kept in the Cambridge University Library.

F. Florentiensis, kept in the Laurentian Library of Florence.

H. Huntingtonianus, kept in the Bodleian Library of Oxford under shelfmark I87.

L. Lipsiensis, kept in the Leipzig University Library.

M. Marshianus, kept in the Bodleian Library of Oxford under shelfmark I88.

R. Romanus, kept in the Museum of the Propaganda in Rome.

S. Socinianus, one of the oriental language manuscripts (in the library) of Albert Socin, professor at Tübingen.

Ss. Another Socinianus.

The manuscripts may be divided into three sets.

The first set is constituted of oriental, specifically 'Nestorian,'* manuscripts, which I denote with the letters BRSSs. B is a fragment of an old manuscript, completed with a supplement copied out of another manuscript in the year 1883 . $R$ consists of four volumes, which were copied at various times. The third volume, which proceeds from the letter, to the letter $\rightarrow$, I conjecture was at one time the second volume of the manuscript $S s$, on the basis of the evidence of several signs in the incipit. Ss provides only the third part of the lexicon and ends after $\downarrow$; its first pages, up to the words

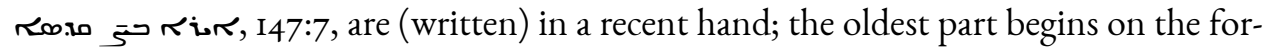
ty-first page. Written in the year 1796, S contains the entire lexicon; it follows precisely the manuscript $\mathrm{S} s$, but not a few words have been added from Bar 'Ali's lexicon. The

\footnotetext{
* Quotation marks have been added to Duval's use of the terms 'Jacobite' and 'Nestorian' by the Editors of the present volume.
} 
oldest of these manuscripts is $\mathrm{S} s$, which was written in the year $12 \mathrm{I} 4$ (22 Ab in the year 6II of the Arabian age). The final volume of manuscript $\mathrm{R}$ gives the year I5o8, but parts of the first are undoubtedly much older. A note to this manuscript in Italian assigns it to the year $1233-1234$ with the words 'This manuscript was written in year 63I of the Hijra.' I do not know whence the author of the note gained his knowledge, but I do not doubt that at one time there was a note in the title which is now lost; part of the first page of the manuscript has been effaced. I refer to the i6th century the old manuscript written in 'Nestorian' script of which B is a fragment.

Western manuscripts, 'Jacobite' and Maronite, form the second set, which I denote with the letters CHFM. H, the most outstanding, was completed in the month Kānūn I in the Greek year 1596 (the month of December 1284). CFM were copied from one and the same manuscript which was owned by the monks attached to the monastery of Saint Anthony, and naturally were written in Mount Lebanon: M in the year 1597, C in the year I6oI, and F in the year I606; they do not differ amongst themselves.

The manuscripts of the third set, $\mathrm{AB} b \mathrm{~B} b b \mathrm{~B} b b b \mathrm{~L}$, include the glosses of the lexicographers Bar 'Ali and Bar Bahlul altogether, due to which fact they are of little value for the edition of the lexicon of Bar Bahlul.

I have consulted all of the manuscripts HFSSs, that, at my request, the custodians of the Bodleian library, of the Laurentian library, and my friend Albert Socin, separately, kindly sent to Paris, all of the various readings of which you will discover in these pages; moreover, in many places I have inspected and noted the other manuscripts. I have reported the incipits of each of the manuscripts so that anyone may evaluate their mutual relationships. I have omitted all of the copies that Bernstein took upon himself to prepare from several manuscripts, which are kept in the royal library of Berlin under the shelfmarks 542-544, but I have inspected carefully the lexicon of Bar 'Ali using Hoffmann's edition and Paris manuscript 255. This manuscript is replete with vocabulary that is lacking in Hoffmann's edition. In the notes this is designated: B. Ali, Paris. 255; Hoffman's own edition is noted with these words: B. Ali Hoff., or simply: B. Ali.

Concerning the sources of Bar Bahlul's lexicon, which, as I mentioned above, will be discussed later, a little will now suffice. Concerning the lexicographer who sometimes is called Zachariah, المروزي , آتخفiا, I would recall (that he) is one and the same, cf. inf. col. 3:3. Concerning that which pertains to the Book of Paradise, the following may be noted: In the western manuscripts, CHFM, this book is designated thusly: حم

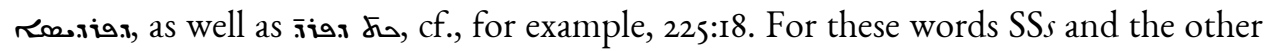




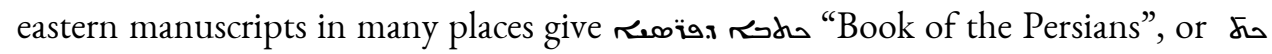
эัта.. The true reading of this will be considered in part of the preface; now it must be mentioned that the various readings of this sort in the manuscripts SSs are noted up to

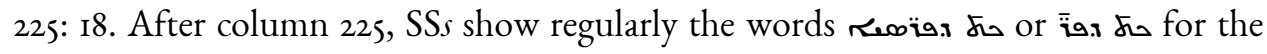

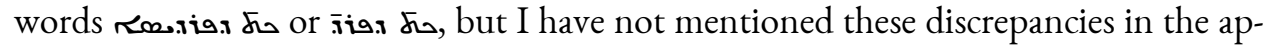
paratus. Thus, after column 225, whenever the gloss roa.xiax do u w occurs, and no

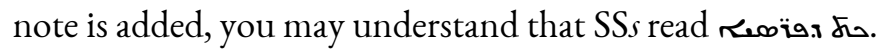

You have a Syriac and Arabic text scrupulously maintained. While the forms of the letters of the Arabic glosses are assumed in certain manuscripts, these common forms are given (expressly) in others; but where all the manuscripts are in agreement, I have not dared to change anything; nevertheless, I have added a diacritical mark at certain times, where the sense required it, to wit: I. The two points of the letter a, which are often lacking; 2. Hamza, in "water," for example, in order that it not be con-

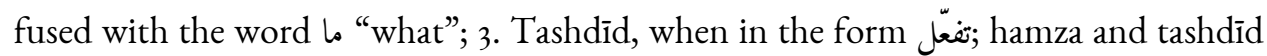
are commonly depicted and rarely omitted. In fact, many of the vocalizations of words are not found in the old manuscripts. I give these out of manuscripts $\mathrm{H}$ and $\mathrm{S}$ s, but take care not to accord them too much value; words which a later scribe has added have at times been a cause for me to repent. The vocalizations of the Arabic dialects of Syria appear to be written, for example, the word حصرِّم " grape juice" is often pointed حصرم in manuscript H, cf. 67: 3, 189: 7, 191: 2. Notes in the manuscripts in which damma (is given) for kasra or fatḅa not rarely are to be discovered; for the form تَفَُّ the form تفعُّ remains. تفعل ren often occurs, but in our edition only

You may complain of confused words, which, in inverted order, do not have their places; certain (words) are found two or three times in various places in the columns; others occur on the facing page, which you might expect to be on the opposite page. But nothing can be changed without less than the removal of all vestiges of such words as were written by scribes in the margins after the preparation of the work and thereafter handed down as part of the received text. Moreover, in many places repeated words are explained with varying glosses, which if (presented) in one place would have occasioned not little detriment by way of congestion and confusion. Again, for corrupt (items) of vocabulary, I note the place which they occupy, and when it is easy to do so, I restore them, for example: The word, anifor, at 195:24, is found within a

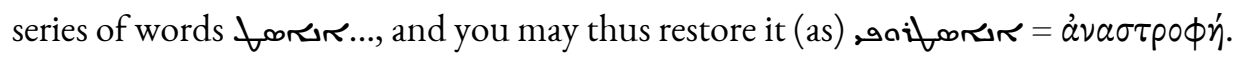

Men well-versed in oriental matters have, previously to the editor, already felt many of the irregular difficulties (that pertain) to the lexicon of Bar Bahlul, first among them Paul Lagarde, who exhibited a most careful way of undertaking the 
work, cf. Gesammelte Abhandlugen, I-5, and Symmicta, 8I and subsequent. Happily Gesenius, Larsow, Bernstein, and above all Payne Smith have partly prepared the way, (the latter) of whom not having been reluctant to excerpt and extract from the Syriac lexicographers in his Thesaurus. Truly, most valuable aid was offered in a willing and most friendly manner by Albertus Socin, professor of oriental languages at Tübingen, and by Immanuel Loew, arch-rabbi of Szeged. (The former) compared the proof of the text with his manuscripts a second time, read sedulously the Arabic glosses, and noted emendations. (The latter), who reviewed the entirety of the lexicon of Bar Bahlul in writing the eminent work Die aramaeischen Pflanzennamen, which he compiled, corrected not a few errors and identified certain malformed Greek words. It is my great pleasure to take this occasion, which is now presented to me, to give to these men my greatest thanks.

Should the typographical art of the edition please you, I ought not to keep from you repayment of praise to Ernest Renan and Barbier de Meynard, who have publicly declared themselves to be supporters of the work undertaken, and who sent to their associates their advice regarding the books to be printed free of charge by the typesetters of the Republic, on account of which Bar Bahlul's lexicon was accepted among those books. Therefore I have ordered their names to be written at the front of the book with a grateful spirit.

Finally, please accept some compensatory interpretations of certain writing conventions to which Bar Bahlul was accustomed:

$$
\operatorname{Riviv}_{5}=\overline{5}
$$

"Manuscript, copy.”

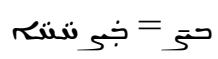

"In a certain manuscript."

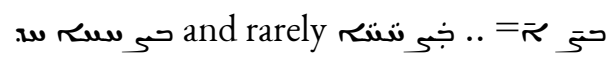

"In another manuscript," "in one manuscript."

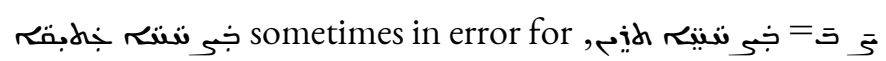

"In two manuscripts", "in an old manuscript."

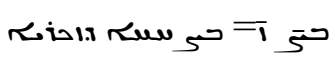

"In a manuscript of Zachariah," but $\bar{\imath}$ sometimes is erroneously given for $\bar{\kappa}$.

$$
\text { حت }
$$


"In an accurate manuscript."

$$
\text { حت }
$$

"In a good manuscript."

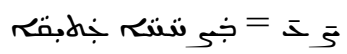

"In an old manuscript."

$$
\text { حi منَ }
$$

"Bar Serošway.”

$$
\text { حi مَّ }
$$

"Bar Serapion, the son of Serapion."

$$
\text { inc } 40
$$

"According to Gabriel Bokhtišo ‘"

$$
\text { صحَ= טبويم }
$$

"Hunayn.”

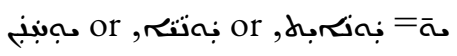

“Greek," or "Septuagint," or "John (the son of Serapion)"

$$
\text { هัต }
$$

“Abdos bar Yazdpanah,” 227:I.

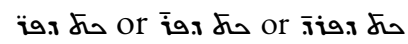

See above.

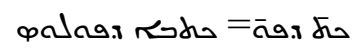

“The book of Paul of Aegina."

$$
\text { סחר }
$$

"Syriac."

“According to Sergius of Reš 'Aynā.”

$$
\text { - is nor }
$$

a do

"According to Paul of Aegina."

Rubens Duval 